BIBLIOTIKA : Jurnal Kajian Perpustakaan dan Informasi

Volume 2 Nomor 1, 2018

Journal homepage : $\underline{\text { http://journal2.um.ac.id/index.php/bibliotika }}$

\title{
Pergeseran Budaya Baca dan Perkembangan Industri Penerbitan Buku di Indonesia: Studi Kasus Pembaca E-Book Melalui Aplikasi iPusnas
}

\author{
Galuh Ayu Puspita, Irwansyah* \\ Pascasarjana Manajemen Komunikasi FISIP, Universitas Indonesia
}

\begin{tabular}{|c|c|}
\hline ARTICLE INFO & A B S T R A C T \\
\hline $\begin{array}{l}\text { Keyword: } \\
\text { Budaya Baca, } \\
\text { Industri Penerbitan Buku, } \\
\text { E-book, } \\
\text { iPusnas }\end{array}$ & $\begin{array}{l}\text { Industri penerbitan buku saat ini memiliki pola yang bergeser, yakni mulai menerbitkan e- } \\
\text { book atau electronic book. E-book diharapkan mampu menjadi sarana membaca yang lebih } \\
\text { mudah diakses ketimbang buku cetak. iPusnas hadir sebagai sarana aplikasi perpustakaan } \\
\text { digital yang dapat diakses tanpa batas. Penelitian ini ingin mengetahui bagaimana iPusnas } \\
\text { dapat mempengaruhi pergeseran budaya baca. Dengan melakukan studi kasus terhadap } \\
\text { pembaca e-book yang mengakses dari iPusnas, diharapkan dapat menghasilkan penelitian } \\
\text { yang menjawab pertanyaan penelitian. }\end{array}$ \\
\hline
\end{tabular}

\section{PENDAHULUAN}

Rendahnya minat baca bagi masyarakat Indonesia adalah rahasia umum yang telah diketahui bersama. Apabila disodorkan antara gadget atau buku, masyarakat akan lebih memilih gadget sebagai sarana untuk menghabiskan waktu. Baik media cetak maupun elektronik ketika membahas mengenai budaya baca di Indonesia akan selalu menyelipkan hasil survei yang menyebutkan bahwa masyarakat kita bukan lah masyarakat yang gemar membaca. Survei ini bahkan diperkuat dengan hasil penelitian dari United Nations Educational, Scientific and Cultural Organization (UNESCO) yang menyebutkan bahwa indeks minat baca di Indonesia hanya sekitar 0,001. Itu artinya hanya ada satu orang yang minat membaca dalam seribu orang masyarakat Indonesia (Liputan6.com, 2017).

Perlu digaris bawahi, data ini hanya menyebutkan minat baca. Belum tentu satu orang tersebut gemar membaca apalagi menjadikannya budaya. Pun, belum tentu bacaan yang dibacanya adalah tulisantulisan berkualitas. Serupa dengan data penelitian dari UNESCO tersebut, Organization for Economic Cooperation and Development (OECD) pun menyebutkan bahwa kemampuan membaca, berhitung, dan pengetahuan sains anak-anak Indonesia masih jauh dibawah negara-negara ASEAN lainnya seperti Singapura, Malaysia, Vietnam, dan Thailand. Tidak hanya OECD, berdasarkan studi "Most Littered Nation in The World" yang dilakukan oleh Central Connecticut State University pada Maret 2016, Indonesia menduduki peringkat buncit, peringkat 60 dari 61 negara mengenai minat baca. Padahal infrastruktur Indonesia berada diurutan ke 34, masih lebih unggul dari Jerman, Portugal, Selandia Baru, dan Korea Selatan (Kompas.com, 2016).

Budaya dengar dan budaya lisan dikalangan masyarakat Indonesia dianggap menjadi penyebab rendahnya minat dan bahkan budaya baca di Indonesia. Masyarakat Indonesia lebih senang mendengarkan pengajian, khotbah, dan orasi dibanding membaca. Selain itu, masyarakat Indonesia juga senang bicara. Mulai dari talkshow di televisi hingga membicarakan hal-hal tidak penting seperti gosip. Sehingga budaya baca dan tulis tidak populer di kalangan masyarakat Indonesia. Sejarah pun mencatat, budaya baca-tulis pada Zaman Kolonial di Indonesia hanya dimiliki oleh "kaum literati" yang tinggal di lingkungan istana. Jadi, budaya ini pun dianggap sebagai budaya elit (Kompas.com, 2016).

\footnotetext{
" Corresponding author.

E-mail addresses: galuh.ayu.puspita@live.com (Galuh Ayu Puspita), dr.irwansyah.ma@gmail.com (Irwansyah)
}

ISSN : 2579-3802 (Online) - BIBLIOTIKA : Jurnal Kajian Perpustakaan dan Informasi is licensed under Creative Commons AttributionShareAlike 4.0 International License (http://creativecommons.org/licenses/BY/4.0/).

13 | BIBLIOTIKA : Jurnal Kajian Perpustakaan dan Informasi 
Berbeda dari Indonesia, Amerika Serikat memiliki minat baca yang lebih tinggi yakni 25-27\% buku pertahun (Tirto.id, 2017). Pun dengan industri penerbitan bukunya. Amerika Serikat mencatat, mereka pernah mencapai masa keemasan pada tahun 1960-1970-an bahkan ketika pertumbuhan ekonomi sedang mengalami penurunan. Pada tahun 1987, jumlah buku yang diterbitkan adalah tertinggi mencapai 56.027 judul. Namun, internet membuat industri ini lesu dan mengakibatkan penurunan jumlah buku yang diterbitkan secara fisik yakni hanya sekitar 49.000 judul dalam beberapa tahun ini (Keh, 1998). Industri penerbitan buku saat ini memang tidak semenjanjikan industri automobile dan industri komputer. Kurangnya penelitian terhadap industri ini menyebabkan industri penerbitan buku tidak populer. Padahal industri ini adalah industri yang unik dan memiliki karakteristik tersendiri.

Tantangan industri penerbitan buku tidak hanya dialami Amerika Serikat tetapi juga Indonesia. Massive-nya penggunaan internet juga ikut mempengaruhi budaya baca masyarakat Indonesia. Saat ini, internet adalah nafas kedua yang manusia tidak dapat hidup tanpanya. Perpustakaan Nasional mencatat, pengguna internet di Indonesia mencapai 132,7 juta jiwa pada tahun 2016 dengan sekitar 86,3 juta jiwa adalah pengguna dari Pulau Jawa (Tribunnews.com, 2017). Sulitnya menanamkan budaya baca di Indonesia semakin terkendala dengan internet. Masyarakat teralihkan keinginan membacanya dari membaca buku menjadi membaca gadget.

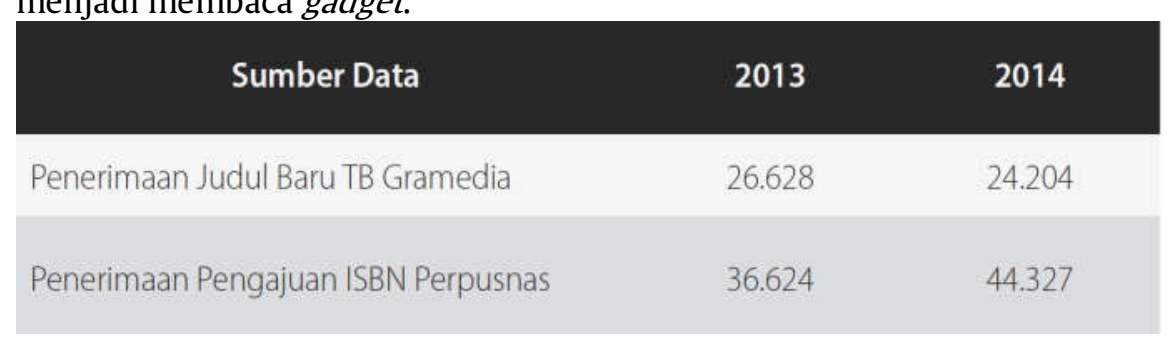

Gambar 1. Produksi Judul Baru Nasional (IKAPI, 2015)

Dari gambar di atas terlihat bahwa pada tahun 2014 terjadi penurunan terhadap judul baru yang diserahkan kepada Gramedia sebagai salah satu penerbit buku besar di Indonesia. Meskipun judul buku yang diterima mengalami penurunan, tetapi terjadi peningkatan dalam permintaan ISBN (International Standard Book Number) di Perpustakaan Nasional RI. Salah satu faktor penyebabnya adalah penulis-penulis mengirimkan hasil karyanya kepada penerbit selain Gramedia. Ada pula lembaga negara maupun Universitas yang menerbitkan sendiri buku mereka.juga, pada tahun 2014, penerbitan buku secara digital juga sudah mulai berkembang. Selain itu, ISBN juga ditujukan tidak hanya bagi buku cetak tetapi juga buku berbasis elektronik atau $e$-book.

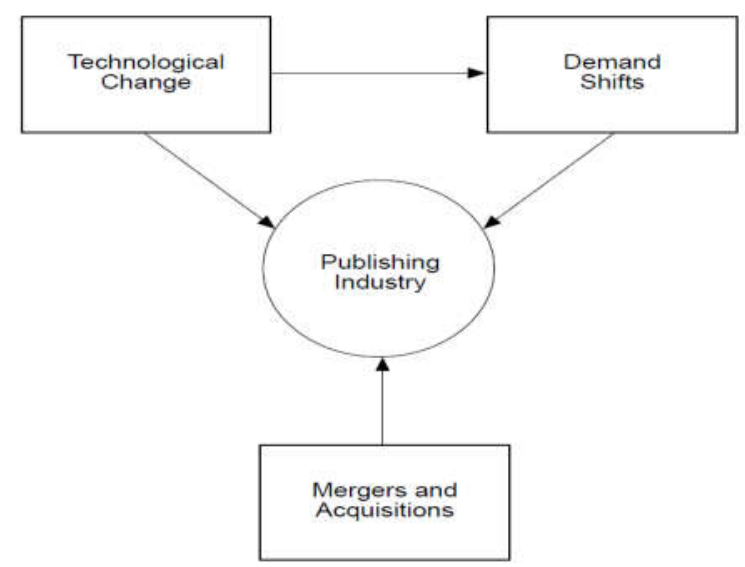

Gambar 2. Tiga hal yang menekan perubahan industri penerbitan buku (Keh, 1998)

Ketika manusia tidak dapat mengalahkan perkembangan teknologi, maka yang perlu dilakukannya adalah membuat inovasi-inovasi yang dapat mendukung perkembangan tersebut. Demikian yang hendak disampaikan Gambar 2 di atas. Perkembangan teknologi menjadi faktor dominan yang membuat industri penerbitan buku perlu melakukan perubahan. Seluruh aspek dalam penerbitan tersebut dipengaruhi oleh perkembangan teknologi. Mulai dari penulisan buku itu sendiri yang menggunakan komputer, hingga sampai dapat dinikmati konsumen.

Selain perkembangan teknologi itu sendiri, tuntutan dari konsumen yang berasal dari generasi melek teknologi juga ikut mempengaruhi industri penerbitan buku. Generasi ini sangat mobile dan lebih ringkas sehingga mereka lebih senang membawa gadget dibanding buku cetak. Muncul kemudian e-book sebagai solusi pemenuhan terhadap kebutuhan membaca generasi mobile ini. 
Merger dan akuisis penerbitan buku bukanlah hal baru dalam industri ini. Akuisis adalah pembelian langsung terhadap sebuah asset yang dianggap sudah pailit, sementara merger adalah penggabungan antara dua atau lebih perusahaan menjadi satu kesatuan (Keh, 1998). Akuisis dan merger menjadi solusi dalam penguatan industri penerbitan buku sehingga terjadi simbiosis mutualisme antara penerbit buku yang sudah tidak mampu lagi berproduksi dengan penerbit besar.

Begitupun dengan dunia industri penerbitan buku Indonesia. Ketika industri penerbitan buku cetak mengalami kelesuan, ada penerbit-penerbit besar yang memanfaatkan kesempatan tersebut dengan menerbitkan buku dalam format digital. Kemunculan penerbit buku digital ini pun akhirnya memunculkan toko buku maupun perpustakaan digital. Meskipun industri e-book sedang mengalami pertumbuhan, tetapi penjualannya masih cukup kecil, yakni hanya 2\% dari pasar buku lokal (IKAPI, 2015).

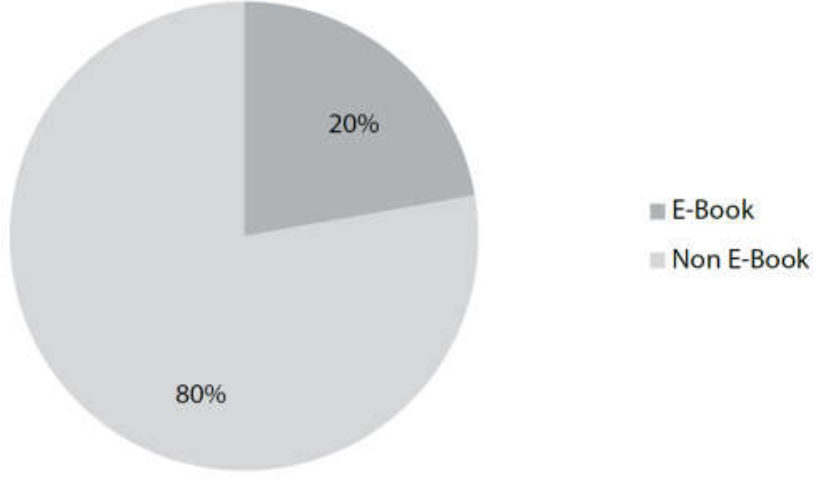

Gambar 3. Pertumbuhan E-Book dan Buku Cetak di Indonesia (IKAPI, 2015)

Diagram di atas menunjukkan bagaimana industri penerbitan buku di Indonesia saat ini bergeser menjadi e-book. Persentasenya bahkan mencapai angka 20\%. Ini artinya penerbit sudah mulai memikirkan perubahan yang akan terjadi di masa depan sehingga media baca konvensional pun bergeser menjadi ke media digital.

Perpustakaan Nasional Republik Indonesia yang memiliki tugas sebagai pelaksana tugas pemerintah dibidang perpustakaan yang berfungsi mengkaji dan menyusun kebijakan nasional bidang perpustakaan serta membina perpustakaan lainnya ini menangkap peluang inovasi dari perkembangan teknologi penerbitan digital. Perpustakaan Nasional saat ini mengembangkan sebuah platform perpustakaan digital yang berbasis aplikasi bernama iPusnas.

iPusnas adalah inovasi baru dalam mendukung budaya baca terutama di Indonesia. Mengusung tagline "Membaca Semakin Mudah", iPusnas menghadirkan buku dalam bentuk e-book sehingga dapat diakses dan dibaca kapan pun dan di mana pun. Hadirnya iPusnas diharapkan mampu membuat minat baca Indonesia dapat meningkat sehingga akhirnya minat baca ini berubah menjadi sebuah budaya baca yang mengakar pada generasi selanjutnya.

Berdasarkan latar belakang di atas maka peneliti ingin mengetahui bagaimana budaya baca bergeser semenjak berkembangnya industri penerbitan digital, terutama setelah adanya aplikasi iPusnas.

\section{METODE PENELITIAN}

Metodologi yang digunakan dalam penelitian ini adalah melalui pendekatan kualitatif dengan paradigma konstruktivis. Konsep pendekatan kualitatif yaitu berusaha menggabungkan dan menganalisa data untuk kemudian dikembangkan menjadi konsep baru, merumuskan definisi utnuk konstruksi utama, dan menghubungkan kesemuanya. Pada penelitian kualitatif yang dibutuhkan adalah deskripsi tersirat yang dituangkan dalam bentuk deskripsi atau narasi dari sebuah tindakan spesifik yang menghubungkan antara ide dengan data (Neuman, 2014). Sementara paradigma konstruktivis adalah asumsi yang dihadirkan oleh individu melalui pengembangan makna subjektif dari hasil pengalaman individu-individu tersebut (Creswell, 2010).

Metode spesifik yang akan digunakan dalam penelitian ini adalah melalui studi kasus. Studi kasus merupakan metode yang digunakan dalam mempelajari, menerangkan, atau menginterpretasikan suatu kasus secara mendalam. Kasus-kasus yang dijelaskan dapat berupa individu, kelompok, organisasi, isu, proses, komunitas, dan lain-lain (Daymon dan Hollowway, 2002). Studi kasus dianggap sebagai metode yang tepat dalam menjawab pertanyaan penelitian yang ingin mengetahui secara mendalam tentang pengalaman pengguna aplikasi perpustakaan digital dan pergeseran minat bacanya.

Teknik pengumpulan data yang dilakukan yaitu dengan melakukan wawancara langsung. Wawancara dilakukan dengan memberikan sejumlah batasan yaitu hanya dilakukan kepada mereka yang gemar membaca yang setidaknya dibuktikan dengan memiliki akun goodreads dan aktif meng-update perkembangan membaca melalui akun tersebut. Selain itu, narasumber yang akan diwawancara juga menginstall dan menggunakan aplikasi IPusnas di gadget mereka.

15 | BIBLIOTIKA : Jurnal Kajian Perpustakaan dan Informasi 


\section{PEMBAHASAN}

\section{Memahami Budaya dan Budaya Baca}

Budaya adalah sesuatu yang tidak lahir serta merta, ia adalah sebuah warisan turun-temurun yang diajarkan orang tua kepada anak, dan seterusnya hingga ke bawah. Konsep budaya memiliki banyak definisi bergantung kepada sudut pandang budaya tersebut. Browaeys dan Price (2011) berpendapat bahwa budaya adalah segala sesuatu yang dipelajari manusia melalui berbagai saluran, bukan hanya sesuatu yang diwarisi tetapi lebih kepada simbol perilaku, norma, dan nilai pemikiran yang dipelajari dari lingkungan sosial.Menurut Liliweri (2002) budaya adalah perilaku yang tertanam, ia merupakan totalitas dari sesuatu yang dipelajari manusia, akumulasi dari pengalaman yang dialihkan secara sosial (disosialisasikan) -tidak sekedar sebuah catatan ringkas-, tetapi dalam bentuk perilaku melalui pembelajaran sosial (social learning). Levo-Henriksson (dalam Liliweri, 2002) mengartikan budaya sebagai seluruh aspek kehidupan sehari-hari atau pandangan hidup, apa pun bentuknya, baik mitos maupun sistem nilai dalam masyarakat. Ross (dalam Liliweri, 2002) bahkan mengatakan bahwa budaya adalah faktor utama dalam pembentukan gaya hidup.

Ada tiga level budaya yang perlu diketahui. Pada level pertama budaya dapat diobservasi dan berbentuk nyata. Yang termasuk ke dalam level ini budaya dimaknai sebagai artefak atau perilaku yang diamati dan terlihat. Level kedua budaya adalah nilai dan norma. Pada level ini budaya menentukan sesuatu di level pertama sebagai sesuatu yang benar atau salah. Pada level ketiga atau level terdalam adalah asumsi dasar. Level ketiga ini sulit untuk diexplore dan apa yang dianggap salah pada level kedua bisa jadi hanya konstruksi dari level-level lainnya.

Membaca adalah proses kognitif yang dilakukan seseorang dengan mengandalkan indera penglihatannya untuk kemudian menterjemahkan dan menginterpretasikan simbol yang muncul dari indera tersebut dari media kertas maupun lainnya. Membaca juga dapat diartikan sebagai proses mengingat, menilai, memikir, mengkhayal, mengorganisasikan pemikiran, dan pemecahan masalah (Kamsul, s.l).

Budaya baca dapat terbentuk dari berbagai aspek. Seperti keinginan atau minat baca yang meningkat dan kemudahan dalam mengakses sumber bacaan. Sehingga budaya baca ini dapat terbentuk. Selain itu frekuensi dan jumlah bacaan yang dibaca juga dapat mempengaruhi terbentuknya budaya baca ini (Harsiati \& Priyatni, 2018).

Membaca juga dapat dijadikan sebagai tolak ukur terhadap kemajuan bangsa karena manfaat-manfaat yang diperoleh dari masyarakat yang senang membaca, antara lain (Kamsul, s.l):

1. Meningkatkan pengetahuan masyarakat

2. Meningkatkan kecerdasan sehingga mampu mengembangkan diri bagi masyarakat

3. Menumbuhkan sikap kritis sehingga mampu mengoreksi hal-hal yang berpotensi merugikan masyarakat

4. Media penyampaian inovasi baru untuk perkembangan masyarakat

Saat ini, membaca bukan lah hal yang sulit untuk dilakukan. Kegiatan membaca bukan lah hal yang mahal seperti pada Zaman Kolonial. Siapapun dapat mengakses buku, baik cetak maupun digital dengan mudah. Perpustakaan hadir sebagai sarana pemenuhan kebutuhan membaca bagi masyarakat yang tidak memiliki daya beli terhadap buku bacaan (Habsari, 2017). Saat ini pun banyak e-book yang beredar di dunia maya yang dapat diunduh secara gratis.

\section{Industri Penerbitan Buku dan Perkembangan E-Book}

Greenhood dan Gentry (dalam Keh,1998) mengungkapkan bahwa industri penerbitan buku modern diawali dengan terbitnya buku yang berjudul Forty-Two Line Bible karangan Johannes Gutenberg. Setelahnya, buku dianggap sebagai kekuatan yang mampu menyebarkan informasi dengan cepat kepada massa yang lebih luas. Industri penerbitan pun lebih simpel yaitu pengarang akan mendekati percetakan dan mendapatkan kontrak untuk menerbitkan juga menjual buku karangannya.

Berkembangnya zaman membuat industri penerbitan buku pun mengalami perubahan terutama setelah perkembangan teknologi. Seperti yang telah disampaikan dalam Gambar 3, industri penerbitan buku dipaksa melakukan perubahan. Seperti penggunaan komputer dan perangkat teknologi lainnya yang lebih canggih dalam memproduksi buku, adanya tekanan dari pasar yang mengalami perubahan teknologi dan generasi, yang akhirnya industri penerbitan harus mencari akal bagaiamana bertahan dari perkembangan tersebut. Dikenal lah yang namanya akuisisi dan merger.

Akuisisi adalah pembelian langsung terhadap sebuah asset yang dianggap sudah pailit, sementara merger adalah penggabungan antara dua atau lebih perusahaan menjadi satu kesatuan (Keh, 1998). Dengan adanya akuisis dan merger ini, penerbit buku yang sudah tidak mampu lagi beroperasi dapat bergabung dan mendapatkan dana dari penerbit besar, tentunya dengan perjanjian yang saling menguntungkan. Tujuannya sama, yaitu menjaga industri penerbitan buku tetap bertahan. 
Fisik buku pun saat ini telah mengalami perubahan. Buku cetak tidak lagi dianggap sebagai sarana penerbitan satu-satunya, e-book kemudian lahir sebagai solusi atas penggunaan gadget yang makin marak di kalangan generasi milenial. Penerbit buku yang cukup besar akan menangkap perkembangan ini sebagai sebuah peluang dalam melakukan inovasi. Mereka membuat versi digital atau $e$-book dari buku cetak atau justru malah hanya menerbitkan dalam bentuk e-book saja. Tidak hanya itu, penerbit di era saat ini tidak lagi menganggap diri mereka sebagai pemasok buku fisik, melainkan ide dan informasi.

E-book atau electronic book diartikan sebagai format penerbitan dengan berbagai jenis seperti teks dalam format digital, buku yang diconvert menjadi digital, platform baca digital, dan lain-lain. Format $e-$ book sendiri pun bermacam-macam. Mulai dari dokumen hingga software tertentu dapat digunakan sebagai format tersebut.

Rao (2004) mengelompokkan e-book menjadi empat kategori berdasarkan implementasi lokasi kontennya, yaitu:

1. E-book yang dapat diunduh yaitu konten yang tersedia di web dan dapat diunduh untuk digunakan dalam personal computer.

2. E-bookyang hanya dapat dibaca dengan menggunakan device tertentu.

3. E-book yang hanya dapat diakses melalui web. Untuk mengunduhnya diharuskan membayar sejumlah biaya.

4. Print-on-demand books yaitu buku yang terhubung langsung dengan printer yang dapat langsung mencetaknya. Biasanya konten yang tersedia dibagi-bagi berdasarkan chapter, tidak full page.

Seperti halnya buku cetak, $e$-book juga memiliki kelebih dan kekurangannya sendiri. Kelebihan $e$ bookyang paling utama adalah buku dapat dibagi dalam berbagai jenis format elektronik dan dapat dicetak sendiri. Kelebihan bagi pengguna atau pembaca adalah dapat diunduh dari internet dengan cepat dibanding harus mengunjungi toko buku atau perpustakaan. Selain itu, e-book juga mudah ditemukan ketika dicari. Bagi penerbit, e-book membuat proses penerbitan menjadi lebih cepat dan mudah. Buku tidak perlu dicetak yang membutuhkan banyak biaya dan ruang yang luas untuk penyimpanannya. Bagi penulis, e-book dapat diterbitkan sendiri secara self-publish dan penulis juga dapat langsung menerima feedback dari pembaca.

Sementara itu, kekurangan dari e-book adalah teknologi e-book saat ini yang belum memadai, termasuk biaya dalam alat baca $e$-book yang terbilang mahal dan anggapan pembaca yang besar terhadap e-book. Selain itu, e-book juga kurang ramah pengguna karena tampilan, dan tidak ramah difabel, terutama penyandang tuna netra yang sangat mengandalkan buku cetak versi huruf braille. Copyright juga menjadi masalah dalam e-book. Pembajakan adalah hal yang tidak dapat dihindari terhadap konten digital yang mudah ditiru.

Di Indoensia sendiri, e-book juga mulai tumbuh dan berkembang seiring dengan maraknya penggunaan internet dan gadget dikalangan masyarakat. Perkembangan e-book mendorong tumbuhnya penerbit dan toko buku digital. Penerbit-penerbit besar seperti Rosdakarya, Gramedia, Mizan, dan beberapa penerbit Universitas mulai mengembangkan e-book store mereka. Ada pula penerbit-penerbit yang tidak terlalu besar memilih untuk merger dengan penerbit besar demi dapat menerbitan format buku dalam bentuk digital. Toko buku-toko buku digital juga mulai bermunculan.

Seperti yang telah disampaikan dalam Gambar 3 di atas, saat ini jumlah e-book mencapai 20\% dari total keseluruhan penerbitan buku. Hal ini mengindikasikan bahwa pertumbuhan e-book mencapai kearah signifikan. Penerbit mulai memperhatikan dan berupaya untuk melakukan perubahan seiring dengan kemajuan dalam bidang komunikasi yang ikut mempengaruhi media baca konvensional dan bergeser ke arah digital. Namun, meskipun e-book sudah mulai berkembang, penjualannya saat ini hanya sekitar $2 \%$ dari total buku yang diterbitkan pada pasar buku lokal. Selain itu jumlah koleksi cetak yang dikonversi menjadi $e$-book pun masih rendah yakni baru 5\% dari judul buku yang diterbitkan dibuat versi $e$-booknya.

\section{Perpustakaan Digital}

Menurut Pendit (dalam Samosir, 2017), perpustakaan digital adalah berbagai organisasi yang menyediakan sumber informasi, termasuk pegawai yang terlatih khusus dalam memilih, mengatur, menawarkan akses, memahami, menyebarkan, menjaga integritas, dan memastikan keutuhan terhadap sebuah karya digital sehingga koleksi dapat tersedia dan terjangkau dengan mudah oleh sekumpulan komunitas atau individu yang membutuhkannya. Perpustakaan digital saat ini adalah terobosan bagi perpustakaan konvensional dalam menyebarkan budaya baca kepada masyarakat Indonesia khususnya. Kemudahan dalam mengakses e-book dan informasi melalui perpustakaan digital diharapkan mampu meningkatkan budaya baca tersebut. Menurut Griffin (dalam Widayanti, 2015) pengembangan perpustakaan digital saat ini dapat dilakukan karena beberapa faktor, yaitu:

1. Teknologi komputer dan komunikasi yang semakin cangging dapat mengumpulkan dan menyebarkan informasi dengan lebih cepat dan luas. 
2. Infrastuktur jaringan yang memadai

3. Informasi berbasis online semakin berkembang luas

4. Akses internet yang memadai dan tersedia dibanyak ruang-ruang publik.

Widyantini (2015) juga menyebutkan alasan perpustakaan digital perlu dikembangkan yaitu perpustakaan konvensional memiliki batasan terhadap aksesibilitas penggunanya. Pengguna perpustakaan yang tinggal jauh dari perpustakaan tidak dapat mengakses perpustakaan dengan cepat dan membutuhkan biaya besar. Titik cari dari perpustakaan konvensional juga terbatas. Selain itu, penggunaan perpustakaan konvensional juga rumit dan memiliki banyak peraturan. Perpustakaan konvensional membutuhkan banyak sumber daya dalam pengelolaannya. Terakhir, perpustakaan konvensional memerlukan ruang fisik yang luas untuk dapat menampung semua koleksinya.

Dalam perkembangan perpustakaan digital, ada yang disebut dengan Library 2.0. Library 2.0 pertama kali diperkenalkan oleh Michael Casey melalui blog yang dilaunchingnya bernama LibraryCurnch pada September 2005. Casey (dalam Kwanya et. al., 2012) dalam blognya menyampaikan pandangannya terhadap keuntungan dalam penggunaan dan pengembangan Web 2.0 akan membuat perpustakaan lebih baik. Library 2.0 dianggap sebagai aplikasi berbasis web yang interaktif, kolaboratif, dan multimedia bagi layanan dan koleksi perpustakaan.

Web 2.0 memungkinkan sebuah data dibuka, ditransformasi, digunakan kembali, dan disebarkan tidak hanya mungkin tetapi juga mudah. Web 2.0 juga memungkinkan transparansi dan hubungan yang saling menghargai antara penulis konten dengan pembaca. Web 2.0 menjadi cikal bakal dari perkembangan perpustakaan berbasis digital. Perpustakaan digital adalah mungkin untuk diterapkan.

Cho (dalam Kwanya et. al., 2012) menegaskan bahwa Library 2.0 adalah transisi antara dunia perpustakaan dengan program dan layanan yang dikirimkan kepada pengguna melalui metode yang baru. Pada Library 2.0 pengguna adalah segalanya. Bahkan platform ini juga menyediakan ruang bagi pengguna untuk dapat saling berinteraksi dan bertukar pikiran dengan teknologi baru.

Perkembangan perpustakaan pun semakin maju setelah mengikuti perkembangan Web 3.0. web 3.0 kemudian membuat perpustakaan meng-upgrade teknologinya menjadi Library 3.0. Belling et. al. (dalam Kwanya et. al, 2012) menjelaskan bahwa Library 3.0 merujuk kepada munculnya teknologi yang menggunakan semantic web, cloud computing, mobile devices, dan peralatan yang telah berdiri dengan baik seperti sistem pencarian yang terintegrasi, memfasilitasi perkembangan, mengelola, dan menyebarkan konten berbasis pengguna melalui kolaborasi antara pengguna perpustakaan digital, para pakar, dan pustakawan. Mereka juga menambahkan bahwa tujuan utama dari Library 3.0 adalah untuk mempromosikan dan membuat koleksi perpustakaan dapat diakses dengan luas, mudah dicari, dan mudah digunakan. Pada Library 3.0, mulai dikembangkan konsep "borderless library”. Dimana perpustakaan tidak lagi terbatas sekat, namun dapat diakses secara massal.

Sementara itu pada perkembangan Library 4.0, konsep "borderless library" semakin diwujudkan dengan tindakan nyata. Perpustakaan digital tidak lagi berbasis web namun mobile. Mobilitas yang tinggi tidak menghalangi pengguna apabila ingin menggunakan perpustakaan. Salah satu perkembangan Library 4.0 adalah adanya aplikasi perpustakaan digital yang siap guna dan berbasis mobile. Aplikasi ini menghancurkan batasan bahwa perpustakaan hanya sebatas tembok saja. Salah satu yang paling terkenal dari Library 4.0 adalah aplikasi perpustakaan digital iPusnas.

\section{iPusnas}

iPusnas adalah salah satu perpustakaan digital berbasis 4.0 milik Perpustakaan Nasional RI dan dikembangkan oleh PT. Woolu Aksara Maya pada tahun 2016. Selain itu, iPusnas adalah aplikasi perpustakaan digital berbasis mobile atau e-mobile library. Mengusung tagline "Membaca Semakin Mudah", iPusnas hadir sebagai solusi terhadap kegemaran budaya membaca masyarakat Indonesia yang masih kecil. Sehingga diharapkan dengan kemudahan akses iPusnas dapat meningkatkan minat baca dan hingga sampai menjadi budaya.

iPusnas menawarkan kelebihan-kelebihan yang tidak dimiliki oleh perpustakaan konvensional diantaranya adalah kemudahan dalam bersosialisasi dan berbagi. iPusnas menawarkan jaringan membangun relasi pertemanan dengan cara saling follow akun iPusnas pengguna. Sebelum dapat merasakan manfaat yang diberikan iPusnas, jangan lupa untuk mendaftar terlebih dahulu. Syarat yang diberikan pun cukup mudah. Hanya dengan memasukkan email dan password untuk kemudian email tersebut akan diverifikasi oleh pihak iPusnas dan kemudian dapat langsung digunakan apabila telah menerima email verifikasi.

Saat ini iPusnas dapat diakses dengan cara mengunduhnya melalui Play Store maupun Apple Store. Cukup dengan melakukan registrasi beberapa menit, kita sudah dapat mengakses perpustakaan digital ini. Layaknya sebuah perpustakaan, iPusnas memungkinkan penggunanya untuk meminjam buku dengan mengunduhnya terlebih dahulu untuk kemudian dibaca offline. Namun, perlu diperhatikan bahwa mengunduh koleksi dari iPusnas tidak serta merta membuat kita memiliki koleksinya dengan utuh untuk 
diri kita sendiri selamanya.iPusnas menggunakan alat baca sendiri yang terkoneksi dengan aplikasinya. Pengguna hanya dapat membaca buku yang sudah dipinjam tetapi tidak dapat menyebarluaskannya untuk umum. E-book tersebut hanya menjadi milik kita dan bertahan selama beberapa hari bergantung kepada waktu peminjaman $e$-book. Bila perpustakaan konvensional kebanyakan masih menerapkan denda sebagai punishment terhadap keterlambatan dalam pengembalian buku, iPusnas tidak akan melakukannya. Secara otomatis bila masa pinjam kita sudah habis, maka buku dengan sendirinya akan hilang dari daftar buku peminjaman kita dan kembali disimpan di dalam sistem cloud iPusnas.

iPusnas menyediakan fitur Legal and Help bagi pengguna baru sehingga pengguna dapat mengetahui tata cara menggunakan aplikasi ini. E-book yang disediakan tergolong lengkap karena terdiri dari koleksi Perpustakaan Nasional RI dan individu, komunitas, maupun lembaga lain yang telah bekerja sama dengan Perpustakaan Nasional dan bersedia koleksi $e$-book nya diletakkan dalam platformiPusnas tersebut. Data Kumparan.com menyebutkan, saat ini iPusnas memiliki koleksi 20.000 judul. Juga telah diunduh oleh 22.352 pemustaka per Mei 2017.

iPusnas merupakan wujud nyata dari konsep "borderless library" tersebut. Dengan iPusnas, perpustakaan tidak lagi dapat diakses terbatas tetapi sudah tidak terbatas. Dalam artian iPusnas dapat diakses tanpa batas, tanpa ruang, dan tanpa pakem-pakem perpustakaan konvensional. Pemustaka tidak akan kesulitan dalam mengakses buku-buku berkualitas karena sudah disediakan melalui iPusnas. Volume buku cetak dengan jumlah halaman yang mencapai ratusan pun tidak akan menjad kendala dalam membawanya karena sudah ada e-book sebagai pengganti buku cetak tersebut dan lebih ringan dibawa kemana pun. Waktu yang dihabiskan untuk berkunjung ke perpustakaan konvensional pun dapat dipangkas dengan adanya iPusnas ini dan dapat diakses selama 24 jam.

Kemudahan-kemudahan yang disediakan oleh iPusnas diharapkan mampu menjawab tantangan zaman dan generasi milenial dalam menggunakan gadget untuk hal-hal positif. Kismayati (dalam Metrotvnews.com, 2016) mengungkapkan gadget saat ini sudah menjadi life style, iPusnas pun diharapkan ikut menjadi bagian dalam life style yang baik tersebut. Sehingga minat baca generasi saat ini tidak hanya membaca media sosial tetapi beralih kepada buku-buku yang lebih dapat memberikan pengetahuan ilmiah.

\section{DAFTAR RUJUKAN}

Al Qurtuby, Sumanto. 2017. Meningkatkan Budaya Baca dan Literasi Masyarakat Indonesia. Diakses melalui http://www.liputan6.com/news/read/3203062/meningkatkan-budaya-baca-dan-literasi-masyarakatindonesia, pada tanggal 4 April 2018. (Artikel internet)

Creswell, John W. 2010. Research Design: Pendekatan Kualitatif, Kuantitaif, dan Mixed. Yogyakarta: Pustaka Pelajar (Buku)

Browaeys, Marie-Joelle dan Price, Roger. 2011. Understanding Cross-Cultural Management $2^{\text {nd }}$ Edition. London: Prentice Hall. (Buku)

Daymon, Christine dan Holloway, Immy. 2002. Qualitative Research Methods in Public Relations and Marketing Communications. London: Routledge. (Buku)

Gewati, Mikhael. 2016. Minat Baca Indonesia Ada di Urutan Ke-60 Dunia. Diakses melalui https://edukasi.kompas.com/read/2016/08/29/07175131/minat.baca.indonesia.ada.di.urutan.ke60.dunia, pada tanggal 4 April 2018.(Artikel internet)

Habsari, Z. (2017). DONGENG SEBAGAI PEMBENTUK KARAKTER ANAK. BIBLIOTIKA: Jurnal Kajian Perpustakaan Dan Informasi, 1(1), 21-29. https://doi.org/10.17977/um008v1i12017p021

Haryanto, Alexander. 2017. Najwa Paparkan Data Soal Rendahnya Minat Baca Indonesia. Diakses melalui https://tirto.id/najwa-paparkan-data-soal-rendahnya-minat-baca-indonesia-cupM, pada tanggal 4 April 2018.(Artikel internet)

Harsiati, T., \& Priyatni, E. T. (2018). KARAKTERISTIK TES LITERASI MEMBACA PADA PROGRAMME FOR INTERNATIONAL STUDENT ASESSMENT (PISA). BIBLIOTIKA : Jurnal Kajian Perpustakaan dan Informasi, 1(2), 1-11.

IKAPI. 2015. Industri Penerbitan Buku Indonesia: Dalam Data dan Fakta. Jakarta: IKAPI. (Buku)

Iswari, Nurul. 2017. Ini Penyebab Rendahnya Minat Baca di Indonesia. Diakses melalui https://kumparan.com/nurul-iswari/ini-penyebab-rendahnya-minat-baca-di-indonesia1504967041086, pada tanggal 4 April 2018.(Artikel internet)

19 | BIBLIOTIKA : Jurnal Kajian Perpustakaan dan Informasi 
Kamsul, Khotijah. S.l. Strategi Pengembangan Minat dan Gemar Membaca. Diakses melalui $e$ dokumen.kemenag.go.id/files/G4pKDLun1338123296.pdf, pada tanggal 4 April 2018.(Artikel dalam jurnal)

Karismakristi, Pelangi. 2016. Bangun Kegemaran Membaca, Perpusnas Rilis iPusnas. Diakses melalui http://news.metrotvnews.com/peristiwa/MkMY8ZDk-bangun-kegemaran-membaca-perpusnas-rilisiPusnas pada tanggal 4 April 2018.(Artikel internet)

Keh, Hean Tat. 1998. Evolution of the Book Publishing Industry: Structural Changes and Strategic Implications. Journal of Management History, Vol. 4 Issue: 2, pp. 104-123. (Artikel dalam jurnal)

Liliweri, Alo. 2002. Makna Budaya dalam Komunikasi Antarbudaya. Yogyakarta: LKiS Pelangi Aksara. (Buku)

Neuman, W. Lawrence. 2014. Social Research Methods: Qualitative and Quantitative Appraoches. $7^{\text {th }}$ ed. Essex: Pearson Education Limited. (Buku)

Rao, Siriginidi Subba. 2004. Electronic Book Technologies: An Overview of The Present Situation. Library Review, Vol. 53 Issue: 7, pp. 363-371.(Artikel dalam jurnal)

Samosir, Fransiska Timoria. 2017. Perkembangan Perpustakaan Digital di Indonesia Dalam Rangka Pelestarian dan Desiminasi Warisan Budaya Bangsa Indonesia (Studi Beberapa Perpustakaan Digital di Indonesia). Prosiding Konferensi Perpustakaan Digital Indonesia 10, pp. 175-187.(Artikel dalam jurnal)

Sugiyarto. 2017. Memprihatinkan, Ternyata MInat Baca Indonesia Duduki Peringkat 60 dari 61 Negara. Diakses melalui https://kumparan.com/nurul-iswari/ini-penyebab-rendahnya-minat-baca-diindonesia-1504967041086, pada tanggal 4 April 2018.(Artikel internet)

Widayanti, Yuyun. 2015. Pengelolaan Perpustakaan Digital. Diakses melalui journal.stainkudus.ac.id/index.php/Libraria/article/download/1579/1448, pada tanggal 4 April 2018.(Artikel dalam jurnal) 